\title{
CFC1 wt Allele
}

National Cancer Institute

\section{Source}

National Cancer Institute. CFC1 wt Allele. NCI Thesaurus. Code C51419.

Human CFC1 wild-type allele is located in the vicinity of 2 q21.1 and is approximately $7 \mathrm{~kb}$ in length. This allele, which encodes cryptic protein, plays a role in intercellular signaling pathways during vertebrate embryogenesis and cellular growth. Mutations in the gene produce variant alleles that result in autosomal visceral heterotaxy. 